\title{
KOROBASI MODEL PENELITIAN: PERSPEKTIF KARL POPPER
}

\author{
Muslimin dan Dariyus \\ muslimin.1975@feb.unila.ac.id ${ }^{\mathrm{a} \ \ltimes}$,dariyus.1960@ gmail.com ${ }^{\mathrm{b}}$
}

\begin{abstract}
This article aims to illustrate how corrobation based on Popper View not separated from scientific approach to develop science. Corrobation, as technical concept of the science path, inherently used by the inductivist in empirical research. Popper, regarding to criticize the inductif approach, proposed experiment as a part to falsifiying dan verifying to the hyphothesis statement. As a result, to integrate those of approaches (inductive and deductive), mixed approach proposed as a corrobative research model.
\end{abstract}

Key Words: Corrobative, Mixed Approach

\begin{abstract}
Abstrak
Artikel ini bertujuan untuk menggambarkan bagaimana korobasi "Popper" tidak dapat dipisahkan dari pendekatan saintifik dalam mengembangkan ilmu pengetahuan. Korobasi, sebuah konsep yang bersifat teknis dalam peta jalan pengembangan pengetahuan, yang merupakan bagian tak terpisahkan dengan para inductivist dalam penelitian-penelitian empiris. Popper, terkait kritiknya terhadap pendekatan pada inductivist, mengajukan eksperimen sebagai bagian dalam tahapan untuk meragukan dan memverifikasi pernyataan hipotesis penelitian. Artikel ini memberikan kesimpulan, bahwa korobasi yang dimaksudkan oleh Popper, merupakan jalan untuk mengintegrasikan pendekatan induktif dan deduktif dalam bentuk pendekatan campuran (mixed).
\end{abstract}

Kata Kunci: Korobatif, Pendekatan Campuran (Mixed).

\section{Latar Belakang}

Popper (1959) memberikan suatu bentuk model pendekatan logika ilmiah dimana peneliti memiliki prediksi ilmiah dalam bentuk logika tanpa proposisi. Hukum pengetahuan ilmiah dalam membuat prediksi didasarkan pada falsibilitas, dimana semua hal memiliki kemungkinan ketidaksesuaian. Dalam posisi yang demikian, maka peneliti akan memiliki arah pengetahuan yang tidak terikat dimana peneliti dapat bertindak yang seharusnya dilakukan sesuai dengan konteks yang terjadi pada objek yang diteliti. Rowbottom (2011a) menyebut pentingnya fungsi imajinatif dalam ilmu pengetahuan melalui pendekatan logika ilmiah Popper.

Rowbottom (2011b) menyebutkan bahwa Popper menekankan pentingnya sikap kritis dan metode kritis yang sesuai untuk para ilmuan. Hal ini berbeda dengan Kuhn yang menekankan pada pentingnya hal-hal yang tidak terjawab oleh teori yang ada saat ini. Popper meletakan pemikiran pada pentingnya meruntuhkan teori yang ada, sedangkan Kuhn didasarkan pada pengembangan dan mempertahankan teori yang ada saat ini. Hal inilah yang mendasari pentingnya keseimbangan dua madzhab besar dari logika pengetahuan ilmiah tersebut.

${ }^{1} \ltimes$ : Corresponding Author 
Keseimbangan inilah yang penting dilakukan oleh Popper dengan apa yang disebutnya sebagai sebuah korobasi. Popper tidak sepenuhnya untuk membongkar teoriteori yang dominan, selama teori tersebut dapat difalsifikasi dan diverifikasi. Tingkat falsibilitas dan tingkat verifikasi merupakan hal prinsip dari korobasi Popper dimana dalam proses tersebut mampu membangun hubungan logika antara teori dan statement dasar yang diterima secara ilmiah. Hubungan logika tersebut, menurut Popper, harus dapat diuji secara ilmiah sehingga teori sesuai dengan ketidakteraturan hukum alam yang membuka tantangantangangan baru dalam ilmu pengetahuan.

Dalam konteks inilah pentingnya apa yang disebut oleh Popper sebagai kuasiinduksi sebagai salah satu langkah korobasi. Melalui kuasi-induktif, pendekatan deduksi diadopsi untuk menguji atau memfalsifikasi teori yang ada. Kuasi induksi adalah titik keseimbangan yang menjadi keterhubungan antara logika Popper dan Kuhn, dimana Popper menekankan pentingnya pendekatan deduksi, sedangkan Kuhn menekankan pada pendekatan induksi. Berdasarkan hal tersebut, rumusan masalah penelitian ini adalah model penelitian apakah yang membuka ruang korborasi kuasi-induksi pendekatan ilmu pengetahuan dalam logika Popper? .

\section{Popper dan Metodologi Ilmiah}

Popper (1959) menyebut adanya faktor psikologis dalam proses pengembangan ilmu pengetahuan, yang umumnya dilakukan dengan pendekatan induktif. Permasalahan utama yang menjadi dasar metodologi logika Popper adalah adanya faktor metafisis dalam pendekatan tersebut, yang mempengaruhi peneliti mengambil kesimpulan. van Vught (1987) menyebutkan apa yang disebut Popper sebagai Problem Masa Depan Hume; dimana Popper mempertanyakan bagaimana bisa mengambil keputusan untuk masa depan, sedangkan kita hanya memiliki pengalaman dan pengetahuan di masa yang lampau. Dalam konteks inilah Popper mendefinisikan apa yang disebutnya sebagai ketidaksesuaian hukum alam, menggantikan apa yang disebut madzhab saintifik sebagai keteraturan hukum alam. Popper memandang penting pendekatan logika ilmiah dengan tidak hanya menggunakan pendekatan induksi, sebagai pendekatan utama yang selama ini dpergunakan oleh mazhab saintifik.

Argumentasi madzhab induksi menekankan pada keteraturan yang diobservasi melalu sejumlah kasus yang itu terbatas (empirisme). Dan hal itu dapat menjadi dasar generalisasi terkait dengan keteraturan untuk kasus yang serupa. Berdasarkan hal tersebut, madzab induktif berpendapat bahwa hal tersebut dapat menjadi dasar formulasi statement umum yang dapat diterapkan untuk masa depan dengan menggunakan asumsi-asumsi sebagai batasan rumusan masa depan yang diformulasikan tersebut. Terkait dengan empirisme dalam madzhab ini, Von Kutschera (1973) melihat empirisme sebagi posisi filosofis yang melihat pengalaman hanya sebagai salah satu sumber dan hanya dapat dijustifikasi melalui pengetahuan yang disintesiskan. Hal ini dicapai melalui dua prinsip formulasi yaitu (1) bahasa ilmu pengetahuan mengandung istilah-isitilah observasi yang didefinisikan secara deskripti dan (2) statement sintesisi secara keseluruhan hanya dapat diobservasi melalui kalimat-kalimat observasi.

Dengan menggunakan argumentasi Hume, Popper mampu meruntuhkan argumentasi inductivist. Hume (dalam van Vught, 1987) berpendapat bahwa tidak dapat argumentasi logis yang tungggal menjadi dasar pengambilan keputusan terhadap suatu fenomena yang tidak pernah dialaminya. Russel (dalam Chalmers, 1976) memberikan gambaran tersebut dengan apa yang disebutnya sebagai kalkun inductivist.

Ayam kalkun setiap paginya makan pada pukul sembilan pagi. Namun demikian, seorang inductivist yang baik, tidak akan mengambil kesimpulan tersebut secara langsung. 
Dia akan menunggunya hingga mendapatkan sejumlah observasi sesuai fakta bahwa ayam kalkun makan setiap pagi pukul sembilan, dan inductivist yang baik tersebut akan membuat observasinya dengan berbagai variasi situasi, misalnya bagaimana pada hari rabu dan kamis, pada cuaca hangat atau dingin, pada hari hujan atau tidak hujan. Setiap harinya inductivist yang baik tersebut menambahkan berbagai variasi statement pada daftar yang dibuatnya. Akhirnya, berdasarkan fakta yang dikumpulkan tersebut, inductivits yang baik tersebut mengambil kesimpulan bahwa Ayam Kalkun makan pagi setiap pukul sembilan. Kesimpulan ini sepertinya tidak mengalam masalah, kecuali pada saat hari natal, ayam kalkun tersebut tidak makan pagi setiap pukul sembilan, tetapi dipotong pada pukul sembilan. Premis ayam kalkun inductivist tersebut mengalami kesalahan kesimpulan.

Atas dasar inilah, Popper menunjukan bahwa kita tidak dapat memformulasi definisi statement sebagai sebuah teori yang selamanya benar. Yang bisa dilakukan adalah mengambil kesimpulan bahwa teori adalah tidak benar. Dengan posisi yang demikian kita dapat melakukan korborasi melalui falsifikasi teori.

\section{Korobasi Model Penelitian}

Rose (1965) mendefinisikan metode saintifik memiliki dua tahapan yaitu; (i) formulasi hipotesisi dan (2) menguji hipotesis tersebut. Apa yang membedakan dengan pengetahuan lainnya adalah pada tahapan kedua dimana hipotesis diuji secara empiris apakah prediksi yang diturunkan dari hipotesis sesuai dengan observasi dan eksperimen yang dilakukan. Hipotesis atau dugaan imajinatif merupakan langkah awal dalam metoda saintifik sebagai dasar untuk mencari kebenaran atau kata kunci untuk menemukan kebenaran melalui pengujian kritis dan empiris. Pendekatan saintifik mengembangkan mekanisme social seperti peer review dan publikasi untuk mengevaluasi hasil kerjanya. Dalam konteks merumuskan general theory, metode saintifik menerapkan system yang sangat ketat dimana dalam prosesnya menempatkan teori tersebut pada posisi statement yang keliru atau hanya mengandung sebagian atau kebenaran sementara untuk diinvestigasi lebih lanjut. Teori tersebut masih memerlukan modifikasi sebagai dasar pertumbuhan ilmu pengetahuan.

Terhadap metode saintifik tersebut, Popper tidak menolak seluruhnya mekanisme yang dikembangkan oleh metode santifik. Popper menekankan pentingnya korborasi sebagai dasar pengembangan ilmu pengatahuan, yang tidak menempatkan pembuktian statement hipotesis tersebut salah atau benar, namun pada posisi sesuai atau tidak sesuai untuk masa saat ini. Dalam konteks inilah didapatkan keseimbangan antara penganut madzhab saintifik yang lebih dogmatis dengan pendekatan Popper yang lebih bersifat revolusionalist. Hal inilah yang disebut Popper sebagai pendekatan kuasi-induktif.

Kuasi-induksi merupakan pengadopsian pendekatan deduksi pada pengembangan teori yang dilakukan melalui pendekatan induksi. Pada pendekatan ini, Popper menekankan pentingnya eksperimen untuk melakukan falsifikasi dan verifikasi teori yang dikembang melalui pendekatan indusksi atau metode saintifik. Peres (2002) menyebutkan bahwa ada kekeliruan dalam memahami logika Popper selama ini. Peres menyebutkan bahwa pernyataan Popper terhadap pendapatnya dalam penggunaan eksperimen dalam ilmu pengetahuan dipahami secara keliru. Popper lebih menekankan bahwa eksperimen merupakan pelengkap dalam pengembangan ilmu pengetahuan, dan bukan sebagai pengganti dari metode saintifik.

Kataria (2016) melihat bahwa perbedaan utama antara pandangan induktif yang dianut oleh metode saintifik dan Popper adalah pada aplikasi pendekatan induktif. Namun keduanya memiliki posisi yang sama dimana menolak null hipotesis. Para peneliti empiris umumnya memiliki posisi yang mendukung statement bahwa hipotesis null hanya dapat 
ditolak dan jika mengamati para peneliti empiris yang menggunakan inferensi statitik, umumnya menggunakan metodologi yang dipergunakan oleh Popperian.

Niiniluoto (1987) melihat bahwa baik rasionalist dan positivist memiliki sudut pandang yang sama dimana ilmu pengetahuan menghasilkan kemajuan koginitif melalui akumulasi kebenaran dimana falsicilitas dipandang sebagai sebuah kesuksesan dari tidak sesuaianya teori yang menghasilkan sebuah kebenaran baru. Dari sudut pandang ini, model penelitian yang mencakup korborasi Popper dapat dilakukan. Dalam proses tersebut, mixed approach atau metoda campuran dengan menggunakan metode kuantitatif dan metode kualitatif. Apa yang disebut sebagai sebuah keseimbangan antara Bayesian dan Popperian dapat ditemukan melalui pendekatan ini. Metode campuran, pada prinsipnya memuat definisi teknis dari kuasi-induksi yang dimaksudkan oleh Popper, sebagai sebuah pendekatan metode korobasi ilmu pengetahuan yang menghasilkan pengetahuanpengetahuan baru.

\section{Daftar Pustaka}

A.F. Chalmers, Whtat Is This Thing Called Science? (1976), page 13.

Kataria, M. (2016). Journal of Behavioral and Experimental Economics Confirmation: What is in the evidence? 65, 9-15.

Niiniluoto, I. (1987). Studies in History and Philosophy of Science. The Journal of Science Policy and Research Management, 2(4), 640-641. https://doi.org/10.20801/jsrpim.2.4_640

Peres, A. (2002). Karl Popper and the Copenhagen interpretation. Studies in History and Philosophy of Science Part B - Studies in History and Philosophy of Modern Physics, 33(1), 23-34. https://doi.org/10.1016/S1355-2198(01)00034-X

Popper, K.R., 1959. The Logic of Scientific Discovery. Hutchinson, London

Rose, J. T. (1965). The Scientific Method. In British Medical Journal (Vol. 1, Issue 5428). https://doi.org/10.1136/bmj.1.5428.186-b

Rowbottom, D. P. (2011a). Kuhn vs. Popper on criticism and dogmatism in science. A resolution at the group level. Studies in History and Philosophy of Science, 42, 117124.

Rowbottom, D. P. (2011b). Kuhn vs. Popper on criticism and dogmatism in science: A resolution at the group level. Studies in History and Philosophy of Science Part A, 42(1), 117-124. https://doi.org/10.1016/j.shpsa.2010.11.031

van Vught, F. A. (1987). Pitfalls of forecasting. Fundamental problems for the methodology of forecasting from the philosophy of science. Futures, 19(2), 184-196. https://doi.org/10.1016/0016-3287(87)90050-4

Von Kutschera, F. (1973). Induction and the empiricist model of knowledge. Studies in Logic and the Foundations of Mathematics, 74(C), 345-356. https://doi.org/10.1016/S0049-237X(09)70370-2 